\section{Theoretical Approach between the Soft and Hard Law in the Context of Corporate Hovernance}

Nicolae MĂGDAŞ, Ph. D. Student, Babeş-Bolyai University, Faculty of Economics and Business Administration, Cluj-Napoca, e-mail: nicolae.măgdaş@econ.ubbcluj.ro

Lecturer Melinda Timea FÜLÖP, Ph.D, Babeş-Bolyai University, Faculty of Economics and Business Administration, Cluj-Napoca, e-mail: melinda.fulop@econ.ubbcluj.ro

\section{ABSTRACT}

The proposed study analyzes developments and perspectives of soft and hard law in the context of corporate governance. Thus, at the level of the specialized literature, a series of studies were conducted on the role of effective corporate governance as well as on the evolution and prospects of soft and hard law on information transparency. For the purpose of the analysis, the authors conducted a qualitative study on the evolution and prospect of soft and hard law in the context of corporate governance. The results show that corporate governance has evolved more and more in the post-economic crisis and a greater emphasis is placed on the transparency of the information provided in conjunction with the revival legislation.

Keywords: corporate governance, law, capital market, financial crisis

JEL Classification: M40, M42

To cite this article:

Măgdaş, N., Fülöp, M.T. (2019), Theoretical Approach between the Soft and Hard Law in the Context of Corporate Governance, Audit Financiar, vol. XVII, no. 1(153)/2019, pp. 134-141,

DOI: 10.20869/AUDITF/2019/153/006

To link this article:

http://dx.doi.org/10.20869/AUDITF/2019/153/006

Received: 1.12 .2018

Revised: 3.12 .2018

Accepted: 13.01 .2019 


\section{Introduction}

First of all, we consider that it is necessary to state the importance of this subject. It is a proven fact that history has the tendency of repeating itself, regardless of the domain or area of interest. That is the reason why we think that it is of incontestable relevance to analyze the past, the present and, based on these elements, the future of corporate governance. Is there any potential future of interest for this analysis? Clearly, not. It would be useful to identify and regulate the specific measure that would have the potential to prevent economic failures, even extended to global financial crisis, from happening. This is the desired result, but it is far from the reachable and even a partial improvement could serve as a real success.

Why is now the proper moment for such an analysis? Because some of the panic and turbulence caused by the relatively recent global financial crisis have started to fade, leaving a better view upon the major factors that triggered the financial crisis and the mechanism that allowed it to expand. This is the perfect example that history tends to repeat itself. One of the major factors was, the same as for the financial crisis that occurred at the beginning of the precedent century, either the failure of corporate governance regulation, or improper appliance of such regulations. Analyzing how corporate governance failed to play its role and stop or at least help at damage control is of crucial importance to be able to correct the flaws as soon as possible. Prompt action must be taken not only to develop regulations that could prevent future crisis from emerging, but also to be able to recover faster from the current crisis, which we consider not to be fully over.

This paper has the scope of analyzing some of the regulations that are connected with the stated status quo, the way they were influence by the latest crisis and how they reacted to change depending on the domain they were implemented in.

\section{Research methodology}

Currently, the speciality literature defines the methods of scientific incursion and text construction of a paper as being a "way" to be followed in the research activity for fulfilling the objectives, namely for informing and training. The procedures, techniques and instruments used in the scientific incursion are components of the method, viewed as support elements or concrete ways for its capitalisation (Gray et al., 2007, Dunbar and Weber, 2014, Kiss et al. 2015)

The research endeavour represents a logical incursion for approaching the evolutions and perspectives of soft and hard law on corporate governance, which is based on a positive research, by trying to explain and predict the actual reporting practices in audit, but in the same time a normative research as well. For reaching the objectives of this research, we rely on a qualitative approach for summarising the aspects which will be discussed in every section. By using an approach from general to particular (Gray et al., 2007), we begin any analysis by presenting the concepts, taking into consideration the discoveries offered by the academic research and professional bodies. In what the human and social sciences concerns, this research is based on the non-participative observation (Lesage and Wechtler, 2012), on the inductive research method, on the document analysis and comparison techniques. The reforms in the corporate governance domain were punctuated by the cross-section method, which is mostly applied to the theoretical aspects, where we presented a historical incursion of the most important reforms in the domain of corporate governance.

\section{Concentual approaches regarding cornorate governance}

After seeing that legal framework for better corporate governance is being elaborated, we consider to be of crucial importance to have a better monitoring of how the legal framework is being implemented in practice. Apparently, there seems not to be a very efficient monitoring of the corporate governance statements that the companies publish. "In most Member States, responsibility for enforcing the obligation to publish is left to investors who, depending on the culture and traditions in their Member State, often take little action. Financial market authorities or stock exchanges and other monitoring bodies work within different legislative frameworks and have developed different practices" (Green Paper, p.19). The main issue is that in most of the Member States they only play a formal role in verifying whether the corporate governance statement has been published. Meanwhile, there are few Member 
States that check if the information provided by the companies is complete or not by the means of either public or specialized authorities.

A more practical and efficient method according to European Commission's Green Paper would be to have the information published by the companies checked whether it is sufficiently comprehensive by so called monitoring bodies such as stock exchanges or securities regulators. This solution arises a problem of objectivity on behalf of the monitoring bodies. The specified bodies or authorities should not have a say on the content of the information disclosed or make business judgments regarding the solutions chosen by the company for that matter. On the other hand, to enhance the desired effect, authorities could rely on publishing the result obtained out of the monitoring activity, indirectly forcing the companies towards more complete transparency. As any legal framework, for this to be effective enough, the use of formal sanctions in case of serious noncompliance could and should be enforced, as it is currently done in Spain for example (Study on Monitoring and Enforcement Practices in Corporate Governance in the Member States, page 63).

The European Commission believes that "one way to improve monitoring could be to define the corporate governance statement as regulated information within the meaning of Article 2(1)(k) of Directive 2004/109/EC and thus make it subject to the powers of competent national authorities laid down in Article 24(4) of the Directive." (Green Paper, p.19). There is one good part in the fact that monitoring bodies in Member States developed different practices in having a great potential for improving the exchange of best practice.

\section{Transposition and application of soft and hard law on corporate governance}

\section{Domains of appliance for corporate governance regulations}

It can be stated that corporate governance "has become a multilevel regulatory laboratory, in which 'hard' law overlaps and intersects with 'soft' law in numerous, fastevolving ways, a traditional approach to the study of corporate or company law as a relatively confined doctrinal area soon reaches its limits" (Sun, W. et al., 2011). Therefore, it is compulsory to analyze some of the main areas of interest in which corporate governance has interactions and notice how those interaction have been influenced by the recent financial crisis. It is known that financial systems around the world can be mainly delimited as being either capital market based systems or bank-based systems.

\section{a) Capital market}

Since the 60's, corporations have suffered a financialization process that has led to significant changes in the corporate regulatory framework. There is no doubt that some form of regulation in the financial sector is justified, and no regulatory system functions well unless it is accompanied by proper regulation and enforcement thereof, but the value of regulation must be determined by both its benefits and its costs.

Compared to other types of markets such as product markets, capital market are well-developed markets and operate in highly regulated environments. A need for further development of existing regulations emerges from the fact that the capital market is an area with numerous opportunities for fraudulent activities such as insider trading or manipulation and incentives to defraud public investors. Therefore, "capital markets are relatively difficult to regulate because, unlike in the bank system, there is no single focal point on which regulators can focus. Regulators must regulate the market entirely, and due to the nature of the capital market, regulatory failure would lead to disaster" (Kieff \& Paredes, 2010).

The next natural question is how to regulate capital markets. Empirical studies have not managed yet to fully identify the benefits of capital market regulation, but United States experience is a good starting point considering the fact that in the U.S. one can find the most advanced capital markets. Suggestions based on U.S. experience clearly show that for capital markets to work properly there is need for three sets of regulation:

- "strong investor protection;

- a strong watchdog or enforcement agency, like the U.S. Securities and Exchange Commission;

- strong regulation of intermediary institutions." (Kieff \& Paredes, 2010).

What needs to be done can be sketched out from the U.S. model, but the complexity of enforcement of capital 
market regulation should not be underestimated. Starting from disclosure regulation cannot work without proper accounting and auditing rules and leading to antifraud rules that can work only sustained by a strong watchdog such as SEC, there are a multitude of factors to be taken into account among with private enforcement and a well-functioning judicial system.

"The Transparency Directive is a minimum harmonisation measure requiring listed companies to disclose acquisitions and disposals of substantial shareholdings, and prescribing minimum content for management reports" (Johnston A., 2009). According to provisions in the mentioned Directive, Member States must require shareholders to notify companies in case the amount of the voting rights "reaches, exceeds or falls below" (Directive 2004/109/EC) various thresholds (set at the lower level, $5 \%$, by most of the states). In case of shareholders agreements of acting in a coordinated manner, either by transferring voting rights or concluding a range of agreements that have implications for corporate control, similar obligations apply. The Directive specifies the information that must be included in the notification given to the company.

There must be made a statement about:

- $\quad$ "the resulting situation in terms of voting rights;

- the chain of controlled undertakings through voting rights are effectively held;

- the date the threshold was crossed or reached;

- the identity of the shareholder and any person entitled to exercise voting rights on the shareholders' behalf" (Directive 2004/109/EC).

The notification does not have implications only regarding the relationship between the shareholders that have this obligation and the company, but also to third persons, the company being obliged to make this information public within three days from receipt.

There are also specific obligations that occur in case of a public listed company, that are enforced by the mentioned Directive and have the purpose to raise the degree of transparency, which was a considerable important factor that caused major problems during the last financial crisis that occurred in 2008-2009. The problem of transparency has tried to be solved following the fact that listed companies are required to:

- $\quad$ "ensure equal treatment for all holders of shares who are in the same position" (Directive
2004/109/EC) as regarded to the supply of information;

- $\quad$ "produce an annual financial report which consists of audited accounts and management report" (Directive 2004/109/EC);

- produce a "half-yearly financial reports, which include condensed financial statements and an interim management report" (Directive 2004/109/EC).

The direct implications of the application of these provisions considering the fact that the report must be certified by the ones responsible is to offer a correct perspective upon the performance of the company's business and position, a realistic view over the main risks and uncertainties that the company faces and last but not least, to comply with the requirements of the Fourth Company Law Directive by producing qualitative as well as quantitative reporting.

"By assisting shareholders to gain a better understanding of the way in which resources are developed, enhanced and allocated within companies, this reflexive solution aims to ensure that corporate management have sufficient autonomy to pursue project which have a longer-time horizon, whilst leaving the existing legal mechanisms of accountability to shareholders intact" (Johnston A., 2009). The important note that has to be made is that the use of quantitative disclosure as a part of reflexive regulatory strategy is at an experimental stage and has to be kept under review, whether it works or not, to ensure that the costs of the exercise can be justified.

There is more to capital market regulations, obligations that occurred after the financial crisis and have to do with the disclosure of corporate governance regime. It is required by law for the listed companies to "include a corporate report governance statement in their annual financial report" (Directive 2006/46/EC). The statement should contain, according to the Directive, relevant information such as the national corporate governance code that the company is subject to, any codes the company voluntarily decided to apply, all important information regarding corporate governance practices applied beyond the requirements under national law and explanations concerning departures from the codes to which it is subject (comply or explain principle). "These far-reaching disclosure obligations, particularly those prescribed by the Takeover Directive, will enable the 
market better to evaluate the possibility of a transfer of corporate control, and to price the company's shares accordingly" (Johnston A., 2009).

In conclusion, numerous regulations regarding capital market and listed companies have been elaborated with high cost and it is time to measure whether the impact was made in the right direction and of the proper amplitude. "Taken together, these regulatory interventions signal an attempt to harness market forces to encourage companies to comply with shareholder preferences as to governance structure, within the existing constraints and possibilities of national company law. Institutional investors might build on this regulatory framework and use their market power to drive convergence on a norm of one share, one vote, without positive harmonisation being required at the supranational level" (Johnston A., 2009). In the end, all these measures aim to encourage shareholders and institutional investors to play a more active role in the governance of the companies they invest in.

\section{b) Credit institutions / Banks}

In this case, the main question is "why?". Why is there need for regulation in the bank system considering the straight forward way it works? Basically, banks fund themselves from the deposits of those who have liquid capital and then loan the money to those who need this kind of capital. The answer finds its sustainability in two main ideas. "One is that it is impractical for dispersed depositors to monitor the bank effectively in an organized fashion because of the collective action problem. Thus, regulators monitor banks on behalf of dispersed depositors" (Dewatripont \& Tirole, 1995). Second, "banks often participate in (and sometimes operate) payment systems that inevitably accompany systemic risk, thus producing a negative externality. Failure of one payment transaction may lead to disaster, so participants call for some form of regulation to deal with this systemic risk" (Goodhart et al.,1998).

Moreover, there is need to analyze what kind of problem could the regulations prevent. Firstly, there the tendency for the banks to either loan more than they can afford or give loans that are not profitable. Partially, this problem has some safe measures in most jurisdictions such as deposit insurance in case of bank failure, rescue measures from the central bank or the government. On the other hand, the banking system faces a lot of various risks because of the different financial assets or failures caused by technological failure.
Bank regulation is designed to respond the risks that affect the banks as centralized risk takers by ensuring proper risk management by the banks. Of the changes brought by these regulations is that banks are obliged to make proper and strict assessments of each loan in the bank's asset portfolio. "These strong and active interventions by regulators are understood to be necessary in the bank system today. While enhancing the transparency of banks is considered important, market discipline is often not practicable, even though academics often argue that it should be" (Kieff \& Paredes, 2010).

The banking environment has today shifted from only facing credit risk to also facing market risk, from economies of scope to economies of scale which tend to create large banking institutions that are hard to monitor properly and from traditional banking business activities to other new business activities. Nowadays, regulatory measures have been altered by the needs and are rather indirect than direct as they used to be in the past. For example, past regulations were developed in such manner that they tried to manage risk by prohibiting risky investments. On the other hand, regulations developed in present have an indirect approach towards risk and analyses only capital, counting on the fact that capital regulation has other pillars to rely on, such as internal control and accounting systems of the banks.

In the end, it also comes to the cost of bank regulation which indicates the effectiveness of the measures compared to the prevented risks. "First, there is the cost of providing proper deposit insurance. Second, regulation tries to prevent bank failure by requiring soundness of banks. Third, bank failure results in an enormous cost, as post insolvency treatments often carry very high costs" (Kieff \& Paredes, 2010). The main idea is that this comes to confirm once again that it is better to prevent than to treat.

\section{Lessons from the financial crisis and the way forward}

"The speed and intensity of the panic in 2008 gave financial globalization a bad name in many countries, thereby undermining the credibility and political leverage of institutional investors and hedge funds to press for governance improvements via public ordering"(Sun W. et al., 2011). The Great Recession had a major impact on asset repricing, mainly regarding substantial losses incurred by pension funds in countries all over the world, 
fact which triggered a strong public support for corporate governance reforms, support which is probably directly correlated with the equity exposure of the pension assets in each country. Another effect of asset repricing and also of higher international market correlation have led to an increased incentive for outside investors to put pressure on the firm included in their portfolio for increased alpha performance. "At the same time, the conservative funding strategy adopted by many nonfinancial firms, at least in developed markets, may have attenuated this private ordering leverage." (Sun W. et al., 2011).

The recent financial crisis has its roots in fraudulent behaviour of board members, excessive remuneration levels topped with failure to monitor and oversee. These are the factors that have managed to turn this financial crisis in one of the worst and dangerous financial collapses since the early part of the twentieth century. "Improved decision-making is thus called for in moving corporations to better performance levels" (Useem, 2006). "However, boards are trying to balance their function as compliance officers with their function as shapers of the corporation's future" (Lorsch \& Clark, 2008).

At the same time, another problem occurred - society has begun to reconsider deviant behaviour and as a result the lower levels of conduct are now considered to be acceptable whereas in the past same levels were totally unacceptable. "Thus, even though researchers and commentators have usually linked corporate governance to control are seeing new approaches that call for behavioural and leadership change and the development of a holistic paradigm that is more suitable for the complexities of the twenty-first century" (van Ees et al., 2009).

Basically, the impact of the latest financial crisis and the foregoing analysis and arguments point to the fact that there is obvious need for effective and enforceable regulation, a strengthening of governance codes, a greater focus on ethics and leadership, the enhancement of shareholder voice and last but not least the strengthening of disclosure and transparency. "Other drivers of governance are originating from corporate responsibility and socially responsible investment themes" (Brennan \& Solomon, 2008). There is opportunity for learning from relationship-based systems and this could provide a whole new path, the one where key-stakeholders have greater influence and decision- making rights, this leading as a natural conclusion to a higher level of input into the companies' strategies.

"The importance of incorporating a multidisciplinary perspective in governance appears to be the key to understanding governance failures. Governance research has often been left to accounting and legal academics and it is increasingly evident that this approach is far too narrow. Drawing on a more holistic approach to governance will provide a wider lens through which to view the antecedents and impact of the global financial crisis. In addition, it will provide executives and directors with a range of variables that influence good governance and highlight where the focus should be in introducing good governance practices." (Sun W. et al., 2011).

The conducted analysis clearly leads to the conclusion that there is need for a holistic, even a multidisciplinary approach by integrating multiple lenses and perspectives in understanding corporate governance. This is necessary because corporate governance has gone further that its boarders being connected with several other domains and therefore, in order to be able to correctly asses the current status of corporate governance. Why? The answer is simple and mainly relies in the fact that only by this method the correct and adequate future path for corporate governance could be regulated. "This would enable corporations and the economy to mitigate and to better manage a crisis. In this way, a balance between compliance and behavioural approaches is important - regulation to ensure timely and valid disclosure and good structures, alongside focus on ethics, culture, leadership, power and human resource practices to ensure organizational objectives are met in an ethical manner" (Sun W. et al., 2011).

This being said it is obvious that a purely structural approach does not offer the necessary wide view upon the matter, leading to the need of inclusion of other several processes which would ensure a balance between shareholder and stakeholder needs, internal and external environment. The finally of this change, along with the proper organizational purpose, would clearly bring a more effective governance. It is necessary to understand what makes corporate governance tick. We consider that a better understanding of its major pillars - decision-making process, the boardroom culture or the networks and structures of the decision-makers and elites - would 
contribute to a deeper and richer model of corporate governance.

\section{Conclusions}

After an overview on the past and current situation, there is proof beyond any doubt that more has to be invested in developing stronger, wider and more effective corporate governance regulations. There comes the question of cost, but no matter what the cost may be it is certainly lower than the losses caused by the repeated systemic failures. Although, it is difficult to estimate correctly the cost of regulation and enforcement, at first sight, the cost of regulation in the capital market seems higher (it has to reach a wider range of matters) than in the banking system.

Investing in better regulations for one of these systems, may depend as a choice, on how developed a country's economy is. In smaller economies with not such a developed capital market, investing in regulations for banking system seems more rational as it comes with lower costs as well. On the other hand, in a larger economy, where the capital market is a source for providing capital at cheaper cost, focusing on the development of capital market regulation is wiser considering the fact that the benefits provided by the capital market could outweigh the cost of regulation. Compared to the theoretical analysis, in the real world, the cost of the two systems have to be considered in an aggregate manner as they coexist as globalization of the financial markets allow investors to borrow or fund themselves from foreign markets, this making the situation far more complex.

As a final statement, it could be said that clearly one system does not fit all economies. Although it is the era of globalization, it should not be forgotten the fact that economies still have the tendency of preserving the specifications given by the geographic and legal environment. Therefore, in order to prevent the unfortunate past events from happening once again, when developing new regulation, even it is made in such a manner that it should work worldwide, adjusting it to the specific of each economic system should be of great concern.

Corporate governance is a system that acts and reacts. It is up to the regulating institutions to provide such an input, that the reaction will better suit our purposes.

\section{REFERENCES}

1. $A B I \&$ National Association of Pension Funds, Best Practice on Executive Contracts and Severance - A Joint Statement, initially issued in December 2002

2. Brennan, N. B. and Solomon J. (2008) - Corporate Governance, accountability and mechanisms of accountability: an overview, Accounting, Auditing \& Accountability Journal 2(7):885-906, 2008

3. Communication from the Commission to the European Parliament, the Council, the European Economic and Social Committee and the Committee of the Regions - Action plan: European company law and corporate governance - a modern legal framework for more engaged shareholders and sustainable companies, Strasbourg, 12.12.2012

4. Current reporting rules for undertakings for collective investment in transferable securities (UCITS) and alternative investment fund managers (AIFM) only require providing investors with information on investment objectives and policy, including in particular risk profile, past and expected performance and different costs, see Directives 2009/65/EC and 2011/61/EU

5. Davis St, (2007), Does "Say on Pay" Work? Lessons on Making CEO Compensation Accountable, Policy Briefing No.1, 2007

6. Deloitte, Report on the Impact of the Directors' Remuneration Report Regulations 6, 19-20, Nov. 2004 http://www.dti.gov.uk/cld/Deloitte_ Rep_DRRR_2004.pdf

7. Deutsch C. H. (2008), Say on Pay: A Whisper or a Shout for Shareholders? N.Y. Times, Apr. 6, 2008, at BU9.See Risk Metrics Group

8. Dewatripont M \& Tirole J., (1995), The Prudential Regulation of Banks, MIT Press, Cambridge MA

9. Directive 2004/109/EC of the European Parliament and of the Council, https://eurlex.europa.eu/LexUriServ/LexUriServ.do?uri=OJ:L: 2004:390:0038:0057:EN:PDF 
10. Directive 2006/46/EC of the European Parliament and of the Council of 14 June 2006, https://eurlex.europa.eu/legalcontent/GA/TXT/?uri=CELEX:32006L0046

11. Directive $2007 / 36 / E C$ of the European Parliament and of the council of 11 July 2007 on the exercise of certain rights of shareholders in listed companies https://eur-lex.europa.eu/legalcontent/EN/TXT/?uri=celex\%3A32007L0036

12. Goodhart, C., Hartmann P., Llewellyn D., RojasSuarez L., and Weisbrod S. (1998), Financial Regulation: Why, How and Where Now? New York: Routledge.

13. Green Paper, The EU corporate governance framework, Brussels, 2011, https://publications.europa.eu/en/publicationdetail/-/publication/3eed7997-d40b-4984-8080$31 \mathrm{~d} 7 \mathrm{c} 4 \mathrm{e} 91 \mathrm{fb} 2 /$ language-en

14. Gribben K. (2008), Division Grow Within Say-onPay Movement, Agenda, July 72008 http://papers. ssrn.com/paper.taf?abstract_id $=1262867$

15. Johnston, A. (2009), EC Regulation of Corporate Governance, 2009, Cambridge University Press

16. Kieff, F.S., Paredes T.A., (2010), Perspectives on Corporate Governance, Cambridge University Press
17. Lorsch, J.W. and Clark, R.C. (2008) - Leading from the boardroom, Harvard Business Review 86(4):104-11, 2008

18. New UK Stewardship Code for Institutional Investors, Fresh fields Bruckhaus Deringer LLP, July 2010

19. Statement by the European Corporate Governance Forum of 23 March 2009 https://ec.europa.eu/

20. Study on Monitoring and Enforcement Practices in Corporate Governance in the Member States http://ecoda.org/uploads/media/REPORT__2009_09_23_CoE_RiskMetrics.pdf

21. Sun W., Stewart J. \&Pollard D. (2011) - Corporate Governance and the Global Financial Crisis, Cambridge University Press, 2011

22. Useem $\mathrm{M}(2006)$. - How well-run boards make decisions, Harvard Business Review 84(11):130-8, 2006

23. van Ees, H., Gabrielsson, J. and Huse M.(2009) Toward a behavioral theory of the boards and corporate governance, Corporate Governance: An International Review 17(3):307-19, 2009

24. Walker, D. (2009), A review of corporate governance in UK banks and other financial industry entities - Final Recommendations, London 